\title{
Gene Effects for Fruit Yield and Its Component Traits in Cucumber (Cucumis sativus L.)
}

\author{
P. Shabarish Rai", Ravindra Mulge, M.S. Kulkarni, T.B. Allolli, \\ N.K. Hegde and G. Prabhuling
}

Department of Vegetable Sciences, Kittur Rani Channamma College of Horticulture, Arabhavi-591218, Karnataka, India

*Corresponding author

\begin{tabular}{l} 
Ke y w or d s \\
$\begin{array}{l}\text { Cucumis sativus, Gene } \\
\text { effects, Generation mean } \\
\text { analysis, Epistasis }\end{array}$ \\
Article Info \\
$\begin{array}{l}\text { Accepted: } \\
\text { 02 May } 2018 \\
\text { Available Online: } \\
\text { 10 June } 2018\end{array}$ \\
\hline
\end{tabular}

\section{A B S T R A C T}

Generation mean analysis in cucumber is carried out to study gene effects for fruit yield and its component traits (number of branches per vine, sex ratio, number of fruits per vine, fruit length, fruit width, average fruit weight and fruit yield per vine) using three crosses viz., ACS12-29 x Belgaum Local, ACS12-31 x B19, ACS12-51 x Poinsett, $\mathrm{F}_{1}, \mathrm{~F}_{2}, \mathrm{BC}_{1}$ and $\mathrm{BC}_{2}$ generation in Rabi season at Kittur Rani Channamma College of Horticulture, Arabhavi, Belagavi district (Karnataka), India. Results indicated that additive gene effect was found significant in all three crosses for sex ratio (M: F), number of fruits per vine, average fruit weight, fruit length and fruit width. In crosses ACS12-31 x B19 and ACS12$51 \mathrm{x}$ Poinsett additive gene effect was predominant for fruit yield per vine and fruit yield per hectare. In ACS12-29 x Belgaum Local and ACS12-51 x Poinsett dominant gene effect was predominant for sex ratio, number of fruits per vine, fruit yield per hectare, fruit yield per vine and pericarp thickness. Additive $\mathrm{x}$ dominance gene action found predominant in crosses ACS12-29 x Belgaum Local and ACS12-51 x Poinsett for average fruit weight and in cross ACS12-31 x B19 for number of fruits per vine.

\section{Introduction}

Cucumber (Cucumis sativus L.) is a member of the family Cucurbitaceae, with chromosome number of $2 n=14$. It is a highly cross-pollinated crop and usually monoecious in nature preferring warm weather and bright light for its better growth and development. Poor yield is the major concern in cucumber cultivation. The reduced marketability of the fruit is due to the misshapen fruits. Inspite of the extensive cultivation and consumption, cucumbers have not much been taken up for systematic research work in order to understand the genetic architecture and endeavor in crop improvement programs in India. Generation mean analysis is an important tool to estimate and partition total genetic variance into mean [m], additive [d], dominance $[\mathrm{h}]$, additive $\times$ additive [i], additive $x$ dominance [j] and dominant $x$ dominant [1] interactions. This technique also provides information about presence or absence of epistasis. Gene action can vary from one population to another in the same crop and genetic studies are essential for a given 
genetic stock before we employ any breeding method for crop improvement. Estimation of genetic parameters is needed to understand the genetic architecture of yield and yield contributing components. Information about mode of inheritance, type of gene action (Hayman, 1958) and heritability of all the yield attributing components would be of immense help for plant breeder to decide about the suitable breeding procedure to be adopted and the characters on which the selection has to be made.

\section{Materials and Methods}

The experiment comprising of three crosses viz., ACS12-29 x Belgaum Local, ACS12-31 x B19, ACS12-51 x Poinsett of cucumber each having two parents, $F_{1}, F_{2}$ and two back crosses $\mathrm{BC}_{1}$ and $\mathrm{BC}_{2}$ were laid out in a randomized block design with two replications during rabi 2014 at Kittur Rani Channamma College of Horticulture, Arabhavi, Belagavi district (Karnataka), India. Parents were crossed to their respective $F_{1}$ hybrids to generate seeds of backcross generation $\left(\mathrm{BC}_{1}\right.$ and $\mathrm{BC}_{2}$ ) and $\mathrm{F}_{1} \mathrm{~s}$ were selfed to generate $\mathrm{F}_{2}$ generation seeds and all parents were selfed. Seeds were sown in rows spaced $1.5 \mathrm{~m}$ with spacing between plants.

In order to get sufficient precision in estimation of variation within each population, one row (10 plants) of $\mathrm{P}_{1}, \mathrm{P}_{2}$ and $\mathrm{F}_{1}$ and two rows (20 plants) of $\mathrm{BC}_{1}$ and $\mathrm{BC}_{2}$ and three rows (30plants) of $\mathrm{F}_{2}$ seeds were sown in each replication. Regular cultural practices were followed as per package of practices of horticultural crops of University of Horticultural Sciences, Bagalkot (Anon., 2012). The estimates of six genetic parameters namely mean $(\mathrm{m})$, additive $(\mathrm{d})$, dominance $(\mathrm{h})$, additive $\times$ additive (i), additive $\times$ dominance (j) and dominance $x$ dominance (l) were worked out by analyzing and partitioning the means of all the six generations by adopting the methods proposed by Jinks and Jones (1958) as well as Hayman (1958).

\section{Results and Discussion}

The estimates of gene effects for yield traits in three crosses of cucumber are presented in Table 1.

\section{Number of branches per vine}

In Cross ACS12-29 x Belgaum Local, both additive $(d)$ and dominance $(h)$ gene actions were significant. Among the non-allelic interaction additive $\mathrm{x}$ additive (i) and dominance $\mathrm{x}$ dominance (l) interactions were significant. Duplicate type of epistasis was found to be operating. Since, high magnitude of dominance gene being present, it is appropriate to follow heterosis breeding or recurrent selection to increase number of branches. In Cross ACS12-31 x B19, only additive gene effect was significant along with additive $\mathrm{x}$ additive, additive $\mathrm{x}$ dominance $(j)$ and dominance $\mathrm{x}$ dominance epistatic interaction. Due to predominance of additive gene effects simple selection can be practiced for improvement of number of branches by handling segregating material of this cross. In cross ACS12-51 x Poinsett, predominance of additive gene effects obtained, suggesting that simple selection can be practiced for improvement of trait using the segregating material. Bairagi et al., (2001) also have reported additive and dominance gene action in cucumber. Due to higher magnitude of additive genes simple selection can be practiced for improvement of trait using the segregating material.

\section{Sex ratio}

All sorts of gene actions with duplicate type of epistasis operating in Cross ACS12-29 $x$ Belgaum Local, hence it is appropriate to follow recurrent selection. In Cross ACS12-31 
x B19, significance of only additive gene effect and non-significance of all non-allelic interaction. Due to the predominance of additive gene effect, simple selection can be practised for improvement of this trait. significance of both additive and dominance gene effects with additive $x$ additive and additive $\mathrm{x}$ dominance type of non-allelic interaction, simple selection can be practised for improvement of the trait using segregating material of Cross-III.

\section{Number of fruits per vine}

Number of fruits per vine, is the most important yield component, which ultimately determines the productivity of the crop. In Cross ACS12-29 x Belgaum Local, both additive and dominance gene effects were found to be significant with significant of additive $x$ additive non-allelic interaction with the presence of duplicate type of epistasis. Due to predominance of additive gene effects in governing the trait, simple selection is useful in increasing number of fruits per vine. In Cross ACS12-31 x B19, generation mean analysis revealed presence of additive gene effects with additive $\mathrm{x}$ dominance interaction and complementary type of epistasis. Therefore, simple selection as well as recurrent selection may be beneficial in improving this trait. Both additive and dominance gene effects were operating in Cross ACS12-51 x Poinsett, hence selection in segregating generation is effective for improvement of this trait. Earlier, Dineshkumar (2001) and Bairagi et al., (2006) have also reported additive and dominance gene effects for number of fruits per vine in cucumber.

\section{Average fruit weight (g)}

Average fruit weight is one of the key yield components, which is positively associated with yield. Hence, giving importance to this trait would be useful for achieving useful results. As additive gene effect was predominant, simple selection or recurrent selection in segregating generation of Cross-I may be advantageous. In Cross ACS12-31 x B19, additive gene effect and dominance $\mathrm{x}$ dominance non-allelic interaction were significant with duplicate with duplicate type of epistasis. Therefore, recurrent selection should be fruitful for improving the trait.

In Cross ACS12-51 x Poinsett, significance of all gene actions along with duplicate type of epistasis was found, due to higher magnitude of dominant genes heterosis breeding or recurrent selection would be the appropriate breeding methods in improving this trait. Dineshkumar (2001) also reported additive, dominant and additive $\mathrm{x}$ dominance gene actions for average fruit weight in cucumber. Hence, recurrent selection or simple selection would be useful in improving the trait.

\section{Fruit length (cm)}

In Cross ACS12-29 x Belgaum Local, significance of both additive and dominance gene effects and significance of additive $x$ additive and dominance $\mathrm{x}$ dominance type of non-allelic interactions. The opposite signs of dominance (negative) and dominance $\mathrm{x}$ dominance (positive) effects indicated the presence of duplicate type of epistasis. This indicated the involvement of both additive and dominance interactions and hence, adoption of recurrent selection could be ideal for improvement of fruit length. Significant additive and dominance gene effects with additive $\mathrm{x}$ dominance and dominance $\mathrm{x}$ dominance non-allelic interactions have been recorded in Cross-II. Due to the presence of higher magnitude of dominant genes, heterosis breeding or recurrent selection might be appropriate breeding methods in improving this trait. In Cross ACS12-51 x Poinsett, higher magnitude of dominant genes prevails. 
Table.1 Estimates of gene effects for yield traits in three crosses of cucumber

\begin{tabular}{|c|c|c|c|c|c|c|c|c|c|c|c|c|c|c|c|}
\hline $\begin{array}{l}\text { Sl. } \\
\text { No. }\end{array}$ & Characters & Crosses & m & SE & D & SE & h & SE & $\mathbf{i}$ & SE & $\mathbf{J}$ & SE & 1 & SE & $\begin{array}{l}\text { Type of } \\
\text { epistasis }\end{array}$ \\
\hline \multirow[t]{3}{*}{1.} & \multirow{3}{*}{$\begin{array}{l}\text { Number of } \\
\text { branches } \\
\text { per vine }\end{array}$} & C-I & $5.23 * *$ & 0.110 & $1.13 * *$ & 0.149 & $-1.28^{*}$ & 0.548 & $-2.28 * *$ & 0.531 & $0.27^{\mathrm{NS}}$ & 0.167 & $3.23 * *$ & 0.788 & D \\
\hline & & C-II & $4.85 * *$ & 0.123 & $0.63 * *$ & 0.152 & $-0.35^{\mathrm{NS}}$ & 0.594 & $-1.35^{*}$ & 0.579 & $1.27 * *$ & 0.172 & $4.10 * *$ & 0.826 & $\mathrm{D}$ \\
\hline & & C-III & $5.18 * *$ & 0.113 & $1.45^{* *}$ & 0.144 & $-0.61^{\mathrm{NS}}$ & 0.551 & $-1.33 *$ & 0.535 & $0.33 * *$ & 0.026 & $5.88 * *$ & 0.777 & $\mathrm{D}$ \\
\hline \multirow[t]{3}{*}{2.} & \multirow[t]{3}{*}{ Sex Ratio } & C-I & $12.27 * *$ & 0.275 & $2.31 * *$ & 0.484 & $6.51 * *$ & 1.492 & $6.95 * *$ & 1.466 & $-0.12^{\mathrm{NS}}$ & 0.547 & $-9.51 * *$ & 2.29 & $\mathrm{D}$ \\
\hline & & C-II & $14.18 * *$ & 0.289 & $2.45^{* *}$ & 0.550 & $-1.99^{\mathrm{NS}}$ & 1.608 & $-3.03^{N S}$ & 1.597 & -0.08 & 0.557 & $2.51^{\mathrm{NS}}$ & 2.51 & $\mathrm{D}$ \\
\hline & & C-III & $13.99 * *$ & 0.445 & $0.75^{*}$ & 0.379 & $-9.08 * *$ & 1.942 & $-8.39 * *$ & 1.936 & $-1.35 * *$ & 0.387 & $0.45^{\mathrm{NS}}$ & 2.36 & $\mathrm{D}$ \\
\hline \multirow[t]{3}{*}{3.} & \multirow{3}{*}{$\begin{array}{l}\text { Number of } \\
\text { fruits per } \\
\text { vine }\end{array}$} & C-I & $17.82 * *$ & 0.314 & $2.40 * *$ & 0.430 & $-5.52 * *$ & 1.534 & $-5.27 * *$ & 1.522 & $-0.30^{\mathrm{NS}}$ & 0.442 & $1.76^{\mathrm{NS}}$ & 2.16 & $\mathrm{D}$ \\
\hline & & C-II & $13.80 * *$ & 0.191 & $-2.55^{* *}$ & 0.377 & $1.10^{\mathrm{NS}}$ & 1.117 & $1.00^{\mathrm{NS}}$ & 1.074 & $0.95 *$ & 0.405 & $0.60^{\mathrm{NS}}$ & 1.79 & $\mathrm{C}$ \\
\hline & & C-III & $18.43 * *$ & 0.401 & $2.60 * *$ & 0.567 & $-5.08 * *$ & 1.973 & $-3.83^{\mathrm{NS}}$ & 1.963 & $-1.15^{\mathrm{NS}}$ & 0.579 & $5.03^{\mathrm{NS}}$ & 2.80 & D \\
\hline \multirow[t]{3}{*}{4.} & \multirow{3}{*}{$\begin{array}{l}\text { Average } \\
\text { fruit weight } \\
(\mathrm{g})\end{array}$} & C-I & $161.83 * *$ & 1.697 & $7.73 * *$ & 2.140 & $6.92^{\mathrm{NS}}$ & 8.031 & $8.72^{\mathrm{NS}}$ & 8.024 & $-10.37 * *$ & 2.156 & $-1.96^{\mathrm{NS}}$ & 10.95 & $\mathrm{D}$ \\
\hline & & C-II & $177.36 * *$ & 2.886 & $19.45^{* *}$ & 2.972 & $8.26^{\mathrm{NS}}$ & 13.003 & $14.33^{\mathrm{NS}}$ & 12.983 & $-4.83^{\mathrm{NS}}$ & 3.024 & $-34.38 *$ & 16.63 & D \\
\hline & & C-III & $135.40 * *$ & 1.634 & $-9.37 * *$ & 1.870 & $53.43 * *$ & 7.551 & $49.85 * *$ & 7.53 & $17.05 * *$ & 1.920 & $-71.65^{* *}$ & 9.99 & $\mathrm{D}$ \\
\hline \multirow[t]{3}{*}{5.} & \multirow{3}{*}{$\begin{array}{l}\text { Fruit length } \\
(\mathrm{cm})\end{array}$} & C-I & $14.03^{* *}$ & 0.228 & $-2.61 * *$ & 0.281 & $5.14 * *$ & 1.080 & $6.51 * *$ & 1.069 & $0.46^{\mathrm{NS}}$ & 0.296 & $-7.37 * *$ & 1.47 & D \\
\hline & & C-II & $21.33^{* *}$ & 0.281 & $3.63 * *$ & 0.360 & $-5.51 * *$ & 1.342 & $-1.58^{\mathrm{NS}}$ & 1.334 & $-5.09 * *$ & 0.372 & $7.89 * *$ & 1.85 & D \\
\hline & & C-III & $11.56 * *$ & 0.226 & $-1.76 * *$ & 0.233 & $8.73 * *$ & 1.028 & $10.60 * *$ & 1.016 & $-0.59 *$ & 0.250 & $-10.51 * *$ & 1.35 & D \\
\hline \multirow[t]{3}{*}{6.} & \multirow{3}{*}{$\begin{array}{l}\text { Fruit width } \\
(\mathrm{cm})\end{array}$} & C-I & $4.58 * *$ & 0.085 & $0.87^{*}$ & 0.079 & $0.08^{\mathrm{NS}}$ & 0.382 & $-0.08^{\mathrm{NS}}$ & 0.376 & $0.48 * *$ & 0.090 & $1.71^{* *}$ & 0.48 & $\mathrm{C}$ \\
\hline & & C-II & $4.19 * *$ & 0.073 & $-0.58 * *$ & 0.077 & $-0.03^{\mathrm{NS}}$ & 0.344 & $0.47^{\mathrm{NS}}$ & 0.329 & $0.23^{*}$ & 0.086 & $0.37^{\mathrm{NS}}$ & 0.47 & D \\
\hline & & C-III & $4.33 * *$ & 0.059 & $0.56^{* *}$ & 0.092 & $0.17^{\mathrm{NS}}$ & 0.318 & $0.17^{\mathrm{NS}}$ & 0.299 & $0.04^{\mathrm{NS}}$ & 0.107 & $1.05^{*}$ & 0.48 & $\mathrm{C}$ \\
\hline \multirow[t]{3}{*}{7.} & \multirow{3}{*}{$\begin{array}{l}\text { Fruit yield } \\
\text { per } \\
\text { vine }(\mathrm{Kg})\end{array}$} & C-I & $2.88 * *$ & 0.061 & $-0.09^{\mathrm{NS}}$ & 0.061 & $-2.01 * *$ & 0.274 & $-1.95^{* *}$ & 0.274 & $-0.74 * *$ & 0.061 & $3.02 * *$ & 0.35 & D \\
\hline & & C-II & $2.30 * *$ & 0.035 & $-0.38 * *$ & 0.069 & $0.19^{\mathrm{NS}}$ & 0.197 & $0.27^{\mathrm{NS}}$ & 0.197 & $-0.08^{\mathrm{NS}}$ & 0.069 & $0.04^{\mathrm{NS}}$ & 0.31 & $\mathrm{C}$ \\
\hline & & C-III & $1.85^{* *}$ & 0.028 & $-0.16 * *$ & 0.045 & $1.50 * *$ & 0.144 & $1.32 * *$ & 0.144 & $-0.07^{\mathrm{NS}}$ & 0.045 & $-0.76^{* *}$ & 0.21 & D \\
\hline & \multicolumn{3}{|c|}{$\begin{array}{l}\text { *Significant at } 5 \% \text { level } \\
\text { C-I = ACS } 12-29 \times \text { Belgaum Local } \\
d=\text { additive } \\
\text { l= dominance } \mathrm{x} \text { dominance }\end{array}$} & & $\begin{array}{l}\text { Significan } \\
\text {-II = ACS } 12 \\
=\text { dominanc } \\
=\text { Compleme }\end{array}$ & $\begin{array}{l}\text { at } 1 \% 1 \\
-31 \times \mathrm{B} 1 \\
\text { ntary typ }\end{array}$ & of epistasis & \multicolumn{4}{|c|}{$\begin{array}{l}\text { SE-Standard error } \\
\text { C-III = ACS12-51 x Poinsett } \\
\mathrm{i}=\text { additive } \mathrm{x} \text { additive } \\
\mathrm{D}=\text { duplicate type of epistasis }\end{array}$} & \multicolumn{3}{|c|}{$\begin{array}{l}\mathrm{NS}=\text { Non-significant } \\
\mathrm{m}=\text { mean } \\
\mathrm{j}=\text { additive } \mathrm{x} \text { dominance }\end{array}$} & \\
\hline
\end{tabular}


Hence, heterosis breeding or recurrent selection would be appropriate breeding methods in improving this trait using crossIII. Dineshkumar (2001), Munshi et al., (2007) and Bairagi (2001) have also reported significance of additive and dominance gene action for fruit length in cucumber.

\section{Fruit width (cm)}

In cross ACS12-29 x Belgaum Local, generation mean analysis revealed, predominance additive gene action with complementary type epistasis. Hence, simple selection can be practised for improvement of the trait using segregating material. In Cross ACS12-31 x B19, additive gene effect found significant along with additive $\mathrm{x}$ dominance non-allelic interaction indicating predominance of additive gene action. Similar results of additive, additive $\mathrm{x}$ dominance gene actions have been reported by Vinaykumar et al., (2014) in muskmelon. Therefore, simple selection as well as recurrent selection may be beneficial in improving the trait. In Cross ACS12-51 x Poinsett, significance of additive gene action and dominance $\mathrm{x}$ dominance nonallelic interaction suggests, adoption of recurrent selection could be ideal for improvement of fruit width.

\section{Fruit yield per vine (Kg)}

Dominance gene effect found significant, along with significance of all non-allelic interactions in Cross-I. This indicates predominance of dominant genes, hence, heterosis breeding or recurrent selection would be appropriate breeding methods in improving the trait. In cross ACS12-31 x B19, only additive gene effect found to be significant and none of non-allelic interaction were found to be significant along with duplicate epistasis. Similar results have been reported by Vinaykumar et al., (2014) in muskmelon. Therefore, for improvement of this trait recurrent selection method is advisable. In Cross ACS12-51 x Poinsett, significance of both additive and dominance gene action, additive $\mathrm{x}$ additive and dominance $\mathrm{x}$ dominance non-allelic interaction was observed. The signs of dominance (negative) and dominance $\mathrm{x}$ dominance (positive) effects indicated the presence of duplicate type of epistasis. Dineshkumar (2001) has also reported additive and additive $\mathrm{x}$ dominance gene action in cucumber. Hence, adoption of recurrent selection can be ideal for improvement of this trait.

\section{Acknowledgments}

The authors would like to thank the Department of Vegetable Sciences, Kittur Rani Channamma College of Horticulture, Arabhavi (UHS, Bagalkot) for facilitating the research work.

\section{References}

Bairagi, S. K, Ram, H. H., Singh, D. K. and Maurya, S. K. 2006. Exploitation of hybrid vigour for yield and attributing traits in cucumber. Indian J. Hort. 62(1): 41-45.

Bairagi, S. K., Singh, D. K. and Hariharram. 2001. Diallel analysis of combining ability in cucumber (Cucumis sativus L.). Prog Hort., 33(2): 178-183.

Dineshkumar, G. D. 2001. Studies on genetic divergence in Cucumber (Cucumis sativus L.). M.Sc. (Hort.) Thesis, Univ. Agri. Sci. Bangalore.

Hayman, B. I. and Mather, K. 1958. The separation of epistatic from additive and dominance variation in generation meas. Heredity. 12: 371-390.

Munshi, A. D., Ravinderkumar and Panda, B. 2007. Studies on genetic components of variation in cucumber (Cucumis sativus L.). Indian J. Hort. 63(2): 213-214. 
Vinaykumar, S. H., Dhanya, V. S. and Mulge, R. 2014. Generation mean analysis of different yield traits in muskmelon
(Cucumis melo L.). Plant Breed. 14(1): 281-284.

\section{How to cite this article:}

Shabarish Rai, P., Ravindra Mulge, M.S. Kulkarni, T.B. Allolli, N.K. Hegde and Prabhuling, G. 2018. Gene Effects for Fruit Yield and Its Component Traits in Cucumber (Cucumis sativus L.). Int.J.Curr.Microbiol.App.Sci. 7(06): 193-198.

doi: https://doi.org/10.20546/ijcmas.2018.706.024 